\title{
REPRODUCTIVE RIGHTS AND FEMALE EDUCATION IN NIGERIA
}

\author{
Kayode Olatunbosun Fayokun*
}

\begin{abstract}
Access to Planned Parenthood methods and new medical technologies are improving the health of women and generating new debates on reproductive rights and women empowerment. This paper set out to appraise the link between reproductive rights and female education in Nigeria. It observed that, Assisted Reproductive Techniques (A.R.T.) have particularly contributed immensely to reproductive health and enhanced reproductive rights, which are pivotal to women development. However, education and knowledge remain a predetermining factor to the enjoyment of women's reproductive rights as one of the necessary parameters in the evaluation of women's health is female access to education. In Nigeria, female education is restricted by a myriad of cultural, religious and socioeconomic inhibitions which have significantly reduced awareness of reproductive choices and obscured reproductive rights. Of course, these are issues which have not only been relevant to the discourse on human rights but also to the discourse on national health and the realisation of MDGs. This paper established a link between increased female education, access to reproductive techniques and rise in the awareness of reproductive rights in Nigeria. The paper concluded that, female education is a key factor in women development and empowerment.
\end{abstract}

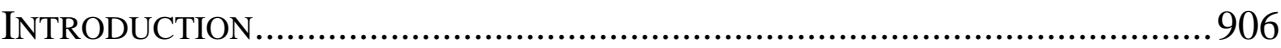

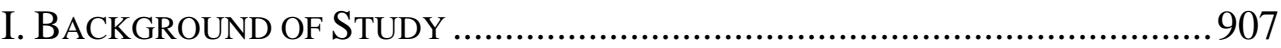

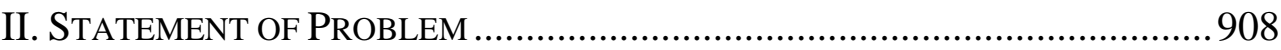

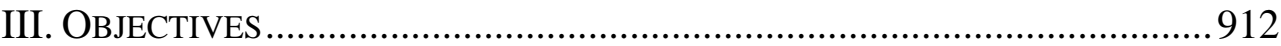

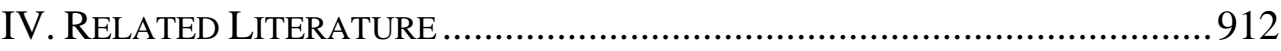

V. FEMALE EDUCATION IN NiGERIA....................................................913

VI. SigNIFICANCE OF FEMALE EDUCATION ............................................917

Conclusion................................................................................ 920

\section{INTRODUCTION}

The Fourth World Conference on Women in Beijing, September, 1995 (the year of the 50th anniversary of the founding of the United Nations), made outstanding Declarations on the rights of women. Based on principles enshrined in earlier international human rights documents (UN Charter, UDHR, CEDAW etc.), the Beijing Declaration set out to ensure the full

\footnotetext{
${ }^{*}$ Ph.D., Faculty of Law, Obafemi Awolowo University, Ile-Ife, Osun State, Nigeria. Research fields: Education Law, Protection of the Vulnerable.
} 
recognition of the rights of women as inalienable, integral and indivisible part of all human rights and fundamental freedoms. It declared in unequivocal terms that, women rights are human rights. Anchored on the Beijing Declaration are whole new vistas of reproductive rights championed by feminist groups. The fringes of these rights have not been well defined. The Beijing Declaration specifically states that:

"The explicit recognition and reaffirmation of the right of all women to control all aspects of their health, in particular their own fertility, is basic to their empowerment”.

Thus, reproductive rights are emerging part of globally recognisable "women rights", although much will still depend on how they are domesticated in our national laws. They have re-opened the abortion debate, issues of gay rights, same-sex marriage, child marriage, a woman's right to control her reproductive health, right to birth control methods or her right of access to Assisted Reproductive Techniques, among other burning issues.

\section{BACKGROUND OF STUDY}

Reproductive rights are an essential aspect of women's rights. Nigeria is a signatory to numerous international treaties on the protection of women with attendant obligations of making her domestic laws keep track of international human right standards. ${ }^{1}$ Planned Parenthood programmes arrived in Nigeria in the seventies when the country enjoyed the oil boom, and having a large family did not bring any economic burden to parents because things were relatively cheaper and there was little or no psychological stress about caring for children. ${ }^{2}$ The programmes brought many contraception methods and were advantageous for the protection of women from unwanted pregnancies. Long before their arrival, traditional methods involving fetishism, prolonged breastfeeding and post partum abstinence were practiced as methods of family control in native communities. Modernisation attributes and women education has greatly eroded those traditional practices.

\footnotetext{
${ }^{1}$ International Human Rights documents relevant to Nigeria include United Nations Charter 1945, Universal Declaration of Human Rights 1948, International Covenant on Civil and Political Rights and its Optional Protocol, International Covenant on Economic, Social and Cultural Rights, African Charter on Human and People's Rights, Convention on the Elimination of all Forms of Discrimination against Women, Beijing Declaration, United Nations Convention on the Rights of the Child, among others.

${ }^{2}$ Ayeni, E. A., Knowledge of Family Planning and Its Effects on the Family: A Case Study in Ile-Ife, Nigeria, 2 GENDER \& DEVELOPMENT IN AfRICA, JOURNAL OF THE CENTRE FOR GENDER \& SOCIAL PoliCy StUdies 32-45 (Ile-Ife: Obafemi Awolowo University 2001).
} 
Education is a critical element in the breakdown of normative traditional behaviour and the embracing of modern technology. Adegbola ${ }^{3}$ in a study observed that, women with no education or with less than five years education have their first births five years before women with eight or more years of education. Christian women have a higher age at first birth than Moslems and traditional religionists. In the same study, it was found that, $68 \%$ of Nigerian women have never heard of any method of contraception, be it effective or ineffective. About $60 \%$ of literate women know at least one method compared with less than 25\% of non-literate women. Nigerian states (e.g., Anambra, Delta and Edo) with high percentage of literate women recorded higher percentage of contraceptive knowledge. Religion and cultural factors as they affect people's behaviour have influence on the use or lack of use of contraceptives. In communities where husbands play dominant roles, their approval of their wives' use of contraceptives are a key determining factor in Planned Parenthood programmes and measures at population control.

The recent introduction of Assisted Reproductive Techniques (A.R.T.) to help infertile women have their own children has been viewed with greater suspicion. Fertility clinics offering A.R.T. procedures are springing up in major African cities including Nigeria. The clinics are mushrooming in notable towns and are offering new reproductive choices to infertile couples. Unlike in Europe however, reproductive choices offered by new medical technologies are highly restricted in Nigeria because of cultural and religious inhibitions. Meanwhile, the ethical and legal problems associated with them remain unaddressed. Nigeria has one of the highest population growth rates in the world and is struggling with a myriad of challenges that have rendered fulfilment of the MDGs a mirage. Against the backdrop of national population health, these issues would require public regulation?

\section{STATEMENT OF PROBLEM}

Women's rights are not only about Feminist views. One may champion reproductive rights, female education and empowerment without necessarily subscribing to feminism. For instance, many issues concerning reproduction have women on the two sides of the debates. As a matter of fact, abortion has some of the most hotly-debated ethical issues, with pro-choice and prolife extremes. Feminists who are pro-choice supporters advocate that, a woman owns her body inclusive of the right to carry a fetus with the legal

\footnotetext{
${ }^{3}$ Adegbola, O., Regional and Socio-Economic Fertility Differential in Nigeria, (1981), quoted by Ayeni, E. A., op.cit., 33.
} 
rights to decide whether or not to bring the pregnancy to full term. This view is countered by pro-life supporters who believe that a fetus is a human being from the time of conception. As such, a fetus has the legal right to life from conception. The most-celebrated judicial incursion into the abortion debate is the case of Roe v. Wade. ${ }^{4}$ Since that, U.S. Supreme Court decision, several countries have passed laws to recognise homosexual unions. Such legislations generally refer to homosexual unions as civil unions or registered partnerships rather than as marriages. These unions usually do not entail the full array of rights to which heterosexual married couples are entitled. Four countries currently legalize gay marriage. They are Belgium, Canada, the Netherlands and Spain.

The gay rights and same-sex marriage advocates have also raised controversial ethical issues. Why should women have their access to new technology to boost their fertility curtailed? Infertility is an age-old medical problem physicians have struggled to overcome. They have made considerable progress, by far the most successful being the birth of Louise Brown $^{5}$ (the "test-tube" baby), in 1978. Since then, embryologists have not ceased to come up with innovations with the hope of solving more of the problems of infertility. Some of the adopted medical procedures, though helpful, are opposed on moral and ethical grounds by ethicists who find them objectionable. On the other hand, are mainstream feminists, who being particularly passionate about the plight of infertile women, fought strenuously to ensure that embryo research was not stultified.

Given the unfavourable cultural and religious climate in many jurisdictions against the use of A.R.T. ${ }^{6}$ procedures, stringent regulations are put in place even in the most advanced countries where the practice is now becoming conventional. In England for instance, it took about twelve years

\footnotetext{
4 "In one of its most controversial and far reaching decisions, the United States Supreme Court in 1973 acknowledged women's constitutional right to an abortion during early stages of pregnancy...Despite its broad sweep, however, the 7-2 ruling fell short of endorsing the abortion-ondemand principle urged by some pro-abortion and women Liberation groups...The right to an abortion, an offshoot of the constitutional 'right to privacy', is a qualified privilege...Justices Byron R. White and William H. Rehnquist dissented, accusing the majority of exercising its 'raw judicial power' by intruding in a matter that 'should be left with the people and to the political processes the people have devised to govern their affairs"”.

${ }^{5}$ A feat of Dr. Patrick Steptoe who invented the "test-tube baby" as a unique assisted reproductive technique. See Dixon Patrick, The Genetic Revolution (London: Kingsway Publication 1993). ${ }^{6}$ A.R.T. is acronym for Assisted Reproductive Technique, a medical practice for solving infertility problems through artificial reproductive means including "in vitro fertilization". In Nigeria, a 14-year jail term awaits any lesbian, gay, bisexual or transgender who engages in illicit union under the Same Sex Prohibition Act (An Act to Prohibit Marriage or Civil Union entered into Between Persons of Same Sex, Solemnisation of Same and for Other Matters Related Therewith).
} 
of intense pressure before Parliament came up with the Human Fertilization and Embryology Act, 1990, a legislative landmark in the regulation of the practice of A.R.T. The Act recognises and regulates the practice of A.R.T. in the U.K. More significantly, it sets a template for other jurisdictions on the role, the law should play in regulating human reproduction in view of emergent trends in embryology research. However, more than two decades after what may be regarded as a defining moment for English law, many African countries are yet to come up with regulations on the use of A.R.T. procedures in their domain.

The lack-lustre stance of many developing countries in addressing the Millennium Development Goals and more particularly the issue of reproductive health is a bane of their under-development: an indication that the communities are not well infused with reproductive choices and rights. Keen observers however, reiterate the fact that, no serious nation can continue to toy with the reproductive health of its citizens. Any nation trifling with the reproduction and population pattern of its people does so at its own peril. For sub-Saharan Africa, mostly faced with grim statistics of poverty, epidemics, political and economic devastation, violent crimes, human rights abuses, refugee crises, illiteracy, alarming maternal mortality rate, etc. meeting the MDGs is still a far cry. The situation it compounded by chronic population planning problems. Substantial parts of uncontrolled population of the developing world are living with HIV/AIDS, Thus, issues bordering on population and reproductive health are central to development planning, since they impact directly on human development indices. ${ }^{7}$ Human reproduction is not merely to be considered from the personal health of the individual but also in terms of the overall health of a nation. To this extent, efforts at providing a remedy for infertility problems should attract a holistic approach.

Those who push for reproductive choices as aspects of human rights consider infertility as individual health condition which may be addressed by the advances in embryology research. ${ }^{8}$ For these proponents, society should welcome the choices offered through A.R.T. and create avenues for further scientific research. It is believed all barriers hindering fertility should soon give way in the face of a favourable research climate. This will

\footnotetext{
${ }^{7}$ Adewuyi A.A., Enhancing and Packaging Knowledge, Project RePORT OF THE BILl AND MeLINDA Gates Sponsored John Hopkins/Obafemi Awolowo University Joint Research ProJect on Reproductive Health 8 (Baltimore: Partnership for Population and Reproductive Health 20032008).

${ }^{8}$ Bennett Ruth V. \& Brown Linder K. Myles, Text Book for Midwives, (ELBS) (12th ed., London 1993).
} 
enhance the reproductive health of a nation's population. ${ }^{9}$ National laws should be geared towards creating access to reproductive choices. Legislative efforts in this direction should be recognising and entrenching reproductive rights into our national laws to reinforce access to new reproductive choices. ${ }^{10}$

Those who oppose A.R.T. on the other hand, harp on moral and ethical instincts. ${ }^{11}$ The argument is that, the natural order for human reproduction which is considered sacrosanct is otherwise subverted. They contend that, God ordained human reproduction only within the confines of holy matrimony. ${ }^{12}$ A.R.T. involves tinkering with the human body in unnatural ways. Man should not play God. To them, legalising free access to A.R.T. is inherently "flawed", since it promotes deviant behaviours like masturbation, artificial insemination, surrogacy, gay practices, etc. ${ }^{13}$ Infusion of society with reproductive rights threatens the moral fabric of the society and leads to unwarranted population explosion among other health and social problems. When U.K.'s Human Tissues and Embryo Bill were being debated for instance, many moral issues were presented before the British Parliament. Questions were asked for example as to whether children born of unknown parentage through in vitro fertilisation would have the rights to know their parents? Would they gain that right at the age of 18 or should have the fact recorded on their birth certificates? Should the statutory provisions retain a "father clause" compelling IVF clinics to make vital disclosures of parentage on demand? How should society handle the devastating consequences of a child discovering the circumstances of his birth at a rather too early stage of life? Should human tissue research be encouraged rather than outlawed or restricted?

The controversies generated by these opposing views are yet to be resolved. ${ }^{14}$ Society must strike a balance between the extreme views. For example, what views should be considered where a desperate woman seeking help to produce just one baby was placed on fertility treatment which made her to produce a set of six viable foetuses? Is there room for selection and destruction of unwanted foetuses or she has no choice? In such

\footnotetext{
${ }^{9}$ Brazier Margaret, Reproductive Rights: Feminism or Patriarchy, THE FUTURE OF HUMAN REPROduCtion: Ethics, ChOICE AND REgulation (Oxford, London: Clarendon Press 1998).

${ }^{10}$ Bennett Ruth V. \& Brown Linda K. Myles, Text BoOK FOR Midwives (ELBS) (12th ed., London 1993).

${ }^{11}$ Harris John \& Holm Sorem, The Future of Human Reproduction: Ethics, ChOICE AND REgulation (Harris John \& Holm Sorem eds., Oxford, London: Clarendon Press 1998).

${ }^{12}$ Dixon Patrick, The Genetic Revolution (London: Kingsway Publications 1993).

${ }^{13}$ Harris John \& Holm SOREM, The Future OF Human ReProduction: ETHICS, ChOICE AND REgulation (Harris John \& Holm Sorem eds., Oxford, London: Clarendon Press 1998).

${ }^{14}$ Dixon Patrick, The Genetic Revolution (London: Kingsway Publications 1993).
} 
a situation what guides the clinician, patrilineal conservative or feminist views? ${ }^{15}$ The question has always been: how far should society go in recognizing free access to reproductive choices?

\section{OBJECTIVES}

The main aim of this study was to ascertain the existence and effectiveness of reproductive rights in Nigeria. The objectives include:

(1) Highlighting the reproductive choices available to Nigerian women;

(2) Itemising the challenges (in terms of awareness and access) to the use of reproductive choices by Nigerian women;

(3) Appraising the effect of education and knowledge on the effective use of reproductive choices and exercise of reproductive rights.

\section{RELATED LITERATURE}

Several writers including Isaac Hebrews Wubon, ${ }^{16}$ Ifedili \& Ifedili, ${ }^{17}$ E. A. Ayeni, ${ }^{18}$ K. K. Abbagana ${ }^{19}$ and a host of others have severally emphasized the importance of female education to national development. "If you educate a male, you educate a man, if you educate a female, you educate a nation", is a usual refrain in their discourses. This is because female education, development and empowerment have been considered a public health issue. The extent to which this is true of reproductive health and women's rights need to be further appreciated. The influx of reproductive choices through Planned Parenthood programmes and new medical technologies in contemporary Nigeria have raised serious ethical and legal issues. How far should we go in recognising reproductive rights?

In a study, carried out on the evaluation of the knowledge of family

\footnotetext{
${ }^{15}$ Harris JoHn \& Holm Sorem, THe Future of Human Reproduction: Ethics, CHOICE AND REgULATION (Harris John \& Holm Sorem eds., Oxford, London: Clarendon Press 1998).

${ }^{16}$ Wubon Hebrews Isaac, Girl-Child Education: Important for National Development, (Jalingo, Nigeria: Dept. of Mass Communication, Taraba State University).

${ }^{17}$ Ifedili C. J. \& Ifedili C. A., Managing Girl-Child Education in Nigerian Universities for Better Productivity, 1(3) EuropeAn Journal of Business AND SoCIAL SCIENCES 96-102 (June 2012). Available at http://www.ejbss.com/recent.aspx.

${ }^{18}$ Ayeni E. A., Knowledge of Family Planning and Its Effects on the Family: A Case Study in Ile-Ife, Nigeria, Gender \& Development in Africa, 2 JOURNAL OF THE CENTRE FOR GENDER \& SOCIAL POLICY STUDIES 32-45 (Ile-Ife: Obafemi Awolowo University 2001).

${ }^{19}$ Abbagana K. K., Female-Child Education: A Critical Issue for National Development in Nigeria, 5(2) JOURNAL OF EDUCATION AND LEADERSHIP DEVELOPMENT (2013).
} 
planning and its effects on Nigerian families, Ayeni ${ }^{20}$ observed inter alia that knowledge of a specific method of contraception is a precondition for its effective application as (conversely) ignorance of a method is deterrence to its use. Also that, educated women are more likely to practice family planning than uneducated ones as education is an important factor in the knowledge of family planning methods. Thus, it remains a question to be asked how accessible reproductive choices and reproductive rights are to Nigerian women.

\section{FEMALE EDUCATION IN NigERIA}

In the Beijing Declaration, governments of participating nations (including Nigeria) resolved as follows:

"We are determined to-

Ensure equal access to and equal treatment of women and men in education and health care and enhance women's sexual and reproductive health as well as education"; (Article 30).

"Promote and protect all human rights of women and girls" (Article31).

Thus, the convergence of opinion is that, female education is inextricably linked with women's sexual and reproductive health. The truth is that, a positive correlation exists between female education and ultimate nation's health. However, females in Nigeria have had various challenges in order to obtain equal education with their male counterpart. ${ }^{21}$ Education is a basic human right and has been recognized as such in international legal documents since the 1948 adoption of the Universal Declaration of Human Rights. ${ }^{22}$ It may be observed for instance that, disproportionate attempts are being made to advance female education and reproductive health. ${ }^{23}$ What has been found as a fact is that, a positive correlation exists between the enrolment of girls in primary schools and the gross national product and increase of life expectancy. ${ }^{24}$ Because of this correlation, concerned calls

\footnotetext{
${ }^{20}$ Knowledge of Family Planning and Its Effects on the Family: A Case Study in Ile-Ife, Nigeria, Gender \& Development in Africa, 2 Journal of THE CENTRE FOR GENDER \& SOCIAL POLICY STUdies, 32-45 (Ile-Ife: Obafemi Awolowo University 2001).

${ }^{21}$ Abbagana K. K., Female-Child Education: A Critical Issue for National Development in Nigeria, 5(2) JOURNAL OF EDUCATION AND LEADERSHIP DEVELOPMENT 1-8 (2013).

${ }^{22}$ See Article 26, UDHR; Section 15, Child's Rights Act, Cap. C50, LFN 2004; and Section 18, CFRN 1999.

${ }^{23}$ Available at

http://en.wikipedia.org/w/index.php?title=Template:Women_society_sidebar\&action=edit.

${ }^{24}$ Available at

http://econ.worldbank.org/WBSITE/EXTERNAL/EXTDEC/EXTRESEARCH/EXTWDRS/EXTWD R2012/.
} 
had been that, all efforts should be geared towards enrolment in schools. ${ }^{25}$ School enrolment usually represent the largest component of the investment in human capital in any society. ${ }^{26}$ Rapid socio-economic development of a nation has been linked with the calibre of its women and their education. ${ }^{27}$ It is obviously clear that, education bestows on women a disposition for lifelong acquisition of knowledge, values, attitudes, competence and skills that are germane to a nation's socio-economic development. ${ }^{28}$

At independence in 1960, there was considerable gender disparity in education in Nigeria. Girls' enrolment figures were particularly very low in Northern Nigeria. ${ }^{29}$ In May, 1961, at a Conference held in Addis Ababa, Ethiopia, ${ }^{30}$ UNESCO's educational plans for Nigeria were announced and a target was set to achieve $100 \%$ universal primary education in Nigeria by the year 1980. The implementation in the 1970s of the free and compulsory Universal Primary Education (UPE) was in line with this plan. ${ }^{31}$ Up until the 1990s, considerably more boys than girls participated in education in Nigeria, though with government's intervention and public awakening, parents began to send and keep their girl children in schools. Consequently, female involvement became more visible in the 1990s. As may be noted, purposeful plans of action led to an increase in females in schools after 1990. Girls' enrolment drastically went up. Although more boys than girls were enrolled in 1991, a difference of 138,000 , by 1998 , the difference was only 69,400 .

At the Pan-African Conference held at Ouagadougou, Burkina Faso, in March and April, 1993, it was observed that, Nigeria was still lagging behind other countries of the world in female access to education. ${ }^{32}$ It was also noted that, gender disparity existed in education and that there was need

\footnotetext{
${ }^{25}$ Abbagana K. K., op.cit.; Wubon Hebrews Isaac, op.cit.

${ }^{26}$ Schultz T. P., Why Governments Should Invest More to Educate Girls, 30(2) WORLD DEVELOPMENT 207-225 (2002).

${ }^{27}$ Nussbaum Martha, Women Education: A Global Challenge, 29(2) JOURNAL OF WOMEN IN CULTURE AND SocIETY 325-355 (2003). Aliu S., The Competitive Drive, New Technologies and Employment: The Human Capital Link, A Paper Presented at the Second Tripartite Conference of Manpower Planners, Chelsea Hotel, Abuja, 2001.

${ }^{28}$ Swann J. \& Graddol D., Gender Equalities in the Classroom Talk, 22(1) EngLish EduCATion 4865 (1988).

${ }^{29}$ Female Education in Nigeria. Available at http://en.wikipedia.org/w/index.php?oldid=613033161.

${ }^{30}$ Conference of African States on the Development of Education in Africa, Addis Ababa, May 15-25, 1961.

${ }^{31}$ UNESCO, Gender and Education for All: The Leap for Equality, Global Monitoring Report 2003/2004. Available at http://www.UNESCO/oc.UNESCO.org/education/eta-report/2003PDF/chapter3.PDF.

${ }^{32}$ UNESCO, The Education of Girls: The Ouagadougou Declaration and Framework of Action, Pan African Conference on the Education for Girls. Available at http://www.unesco.org/education/infomation/nfsunesco/pdf/OUAGAD_E.PDF.
} 
to identify and eliminate all policies that hindered girls' full participation in education. ${ }^{33}$ Gender disparity was still a common phenomenon in schools. The combined gross enrolment for primary, secondary and tertiary schools for female was $57 \%$ compared to $71 \%$ for males in $2002 .{ }^{34}$ This translates into fewer women in certain economic fields as well. The percentages of female workers in some selected professions were as follow: architects $2.4 \%$, quantity surveyors $3.5 \%$, lawyers/jurists $25.4 \%$, lecturers $11.8 \%$, obstetricians and gynaecologists $8.4 \%$, paediatricians $33.3 \%$, media practitioners $18.3 \%$. Issues of gender equality in education have been the subject of much debate during the past decades and have become a prominent topic of debate in all third-world countries. In Nigeria, there are large disparities between the education of boys and girls. Many girls do not have access to adequate education past a certain age. The female adult literacy rate (for ages 15 and above) was put at $59.4 \%$ in comparison to the male adult literacy rate of $74.4 \%$. The gender differences in education are accountable for the gender gap in literacy in Nigeria. ${ }^{35}$

Numerous inter-connected cultural and socio-economic issues prevent women from having adequate access to education in Nigeria. Strong cultural norms restrict the female to the home prescribing the home as the right place for the girl child from infancy to adulthood. According to work done by Denga, ${ }^{36}$ one prominent cultural view is that, it is better for the woman to stay home and learn to tend to her family instead of attending school. Similarly, to explain the fact that, more boys than girls participated in education, another researcher, Obasi,${ }^{37}$ identified a host of constraints with Nigerian traditional beliefs being named as top on the list. Traditional values attach high importance to a woman's conformity with playing her subjected domestic role mostly in the bedroom and the kitchen. A study by the University of Ibadan ${ }^{38}$ linked the imbalance in participation in schooling to the long-held belief in male superiority and female subordination.

Marriage customs also promote early or forced marriage. Thereafter, the woman's role has come to be limited to sexual and domestic labour;

\footnotetext{
${ }^{33}$ Obasi E., (1997), op.cit.

${ }^{34}$ Ojo A., Socio-Economic Situation, Africa AtLASEs (Nigeria) 126-127 (Les J. A. ed., Paris-France 2002).

${ }^{35}$ World Bank Report, 2010.

${ }^{36}$ Denga D. I., EduCATion at a Glance: From Cradle to Tomb (Calabar: Rapid Educational Publishers Ltd. 1993).

${ }^{37}$ Obasi E., Structural Adjustment and Gender Access to Education in Nigeria, 19 GENDER AND EDUCATION 161-177 (1997).

${ }^{38}$ Uwakwe Charles, Ajiobola Falae, Benedict Emunemu \& Omobola Adelore, Impact of Decentralization and Privatization on the Quality of Education in Sub-Saharan Africa: The Nigerian Experience, 7(1) EUROPEAN JOURNAL OF SOCIAL SCIENCES (Nigeria: University of Ibadan 2008).
} 
satisfying the sexual needs of men, working on the farm, carrying loads, rearing and tending babies and preparing food. Recent attempts at dislodging these cultural value systems have met with stiff opposition in communities predominated by Islam showing that, religion also plays a significant role in female subjugation. As Gaidzwanwa ${ }^{39}$ succinctly puts it, the disempowering cultural and religious idea of "female domesticity" as espoused by the practice of "housewification" may be said to have provided the springboard for women's educational imbalance in Africa.

Giving that, the above are some of the major inhibiting factors to female education in Nigeria, the situation was further aggravated by patriarchal practices which gave females no traditional rights to succession. The same patriarchal practices further reinforce the preferences for the boy rather than the girl in the pursuit of education. The economic downturn postdating Nigeria's oil-boom, with declining economic activities, has made education a luxury to many Nigerians, especially those in the rural areas. Nigerian parents are known to invest in children according to sex, birth order or natural endowments, with boys and girls not having exactly equal opportunities. Often the family can only afford to send one child to school. Because daughters have already assumed responsibilities in the home imposed upon them by society, they are less likely to be the ones to attend school. Long before the age of colonialism, rigid ideas about gender perceptions have been imposed on the African mind.

According to the Central Bank of Nigeria ${ }^{40}$, the gender gap in literacy rates at the rural level between boys and girls was 18.3 percent in favour of the boys overall. However, in the age group 6-9 years (primary school ages), it was only 3.9 percent in favour of boys. Other problems associated with female education in Nigeria include high drop-out rates of female students, poor performance, reluctance on the part of female students to enrol in science based courses and poor classroom participation. According to the United Nations Human Development Report (2005) ${ }^{41}$, Nigeria was classified as a low development country in respect of equality in educational accessibility. As such, the overall human development in Nigeria is being hindered by this unevenness in educational accessibility across gender categories.

\footnotetext{
${ }^{39}$ Gaidzwanwa R., Bourgeois Theories of Gender and Feminism and Their Shortcomings with Reference to Southern African Countries, GENDER IN SOUTHERN AFRICA: CONCEPTUAL AND THEORETICAL Issues (Meena R. ed., Harare: Sape Books 1992).

${ }^{40}$ CBN, Annual Reports and Statement of Accounts, December 31, 2000.

${ }^{41}$ UNDP, Human Development Report, New York University Press, 2005.
} 


\section{SigNifiCANCE OF FEMALE EdUCATION}

While most of the Millennium-Development Goals face a deadline of 2015, the gender parity target was set to be achieved a full ten years earlier-an acknowledgement that equal access to education is the foundation for all other development goals. ${ }^{42}$ In countries like Nigeria where resources are dwindling and school facilities are lacking, total school enrolments are found to be low, because a choice must often be made in families between sending a girl or a boy to school. Until equal numbers of girls and boys are in school, it will be impossible to build the knowledge necessary to eradicate poverty and hunger, combat disease, promote reproductive health and ensure environmental sustainability. Infant mortality and women mortality rates will continue to rise, placing the rest of the development agenda at risk. With such bleak scenario, it is extremely important that, girls have access to education. For every additional year girls go to school, they receive 20 percent higher wages and suffer 10 percent fewer child deaths. ${ }^{43}$

Moreover, women with some formal education are more likely to seek medical care, ensure their children are immunized, be better informed about their children's nutritional requirements, and adopt improved sanitation practices. As a result, their infants and children have higher survival rates and tend to be healthier and better nourished. According to The International Centre for Research on Women, ${ }^{44}$ the education that a girl receives is the strongest predictor of the age she will marry and is a critical factor in reducing the prevalence of child marriage. The World Bank estimates that, an additional year of schooling for 1,000 women helps prevent two maternal deaths. ${ }^{45}$ Also, each additional year of formal education that a mother completes translates to her children staying in school an additional one-third to one-half of a year. Following the traditional norm however, girls are not educated since as a girl she is considered a strain on the family's resources. But without education, she cannot even voice her opinion. She lacks the financial as well as emotional strength to stand up for herself, or battle the discrimination from a social pulpit.

\footnotetext{
${ }^{42}$ UNICEF-Goal: Promote Gender Equality and Empower Women, UNICEF-UNICEF Home. Available at http://www.unicef.org/mdg/gender.html.

${ }^{43}$ UNESCO, Education for All by 2015: Will We Make It?, Global Monitoring Report, New York, NY UNESCO/SS/1 UNESDOC, 2008. Available at http://www.ungei.org/resouces/files/154743e.pdf. ${ }^{44}$ Jain Saranga \& and Kathleen Kurz, ICRW Research on Prevalence and Predictors of Child Marriage in Developing Countries, (2006).

${ }^{45}$ UNICEF-State of the World'S Children, (2004). Available at www.unicef.org/socc04/files/Chapter2.pdf.
} 
Additionally, girls are less likely to have access to education as UNESCO noted, due to sexual violence, insecure school environments and inadequate sanitation that adversely affect girls' self-esteem, participation and retention. Inadequacy in terms of curricula, textbooks, laboratory materials and teacher attitudes have sometimes enforced negative stereotypes and have kept girls from receiving the education they need and deserve. ${ }^{46}$ Illiteracy and poverty are gradually being feminised. Many policy analysts consider literacy rates as a crucial measure to enhance a country's human capital. This claim is made on the grounds that, literate people can be trained less expensively than illiterate people, generally have a higher socioeconomic status and enjoy better health and employment prospects. Policy makers also argue that literacy for women increases job opportunities and access to higher education. According to Ojo, ${ }^{47}$ women in Nigeria are harder-hit than men by poverty due to the lack of emphasis placed on female education, and the prevalence of early marriage which tend to further impoverish women, and subject them to statutory discrimination.

The most important ingredient of employment opportunity is education, especially higher education. If employment opportunities are different, standards of living, life expectancies and other parameters of existence and of well-being, will be different. According to Dr. Robert Limlim, UNICEF's Deputy Representative,

"for Nigeria to achieve the goal of being among the largest 20 economies in the world, she must rapidly educate the children, most of all, the girls. Educating girls is known to be the basis for sound economic and social development. Educating girls produces mothers who are educated and who will in turn educate their children, care for their families and provide their children with adequate nutrition. Therefore educating girls translates to better health for the children, reduction in child morbidity and mortality, thus triggering off a snowball effect of achieving all the other MDGs in a sustainable manner."

Today, more children go to school and learn to read and write than in previous decades. As a result, younger persons are much more likely to be literate than older persons. In a survey done by the International Education Statistics, Nigerian literacy was measured across different 5-year age groups. Among persons aged 15 to 19 years-those who were of primary school age

\footnotetext{
${ }^{46}$ Benedicta Ugwulebo A., Female Gender in Professional Examination. FIG Working Week 2011. Bridging the Gap between Cultures, Marketing and Management of Professional SurVey EDUCATION (2011).

${ }^{47}$ Ojo A., Socio-Economic Situation, Africa AtLASEs (Nigeria) 126-127 (Les J. A. ed., Paris-France 2002).

${ }^{48}$ UNICEF Press Release, 2008. Available at www.ungei.org/news/files/Press_release__NGEI_Launch.pdf.
} 
in the 1990s - the literacy rate is $70 \%$. Among persons who are 80 years or older, only $13 \%$ are literate. Additionally, the gap between boys and girls aged $15-19$ is only $11 \%$. The fact remains that, Nigerian women's access to formal education is still being constrained due to their unfair workload within the household division of labour. Consequently, the realization of the MDGs's "gender equality and women empowerment", targets is being impeded harshly. Moreover, according to Bhavani, ${ }^{49}$ such unequal social and gender gaps needs to be bridged in order to take women out of want and poverty.

A 2007 UNESCO and UNICEF joint report addressed the issue of education from a rights- based approach. ${ }^{50}$ Three interrelated rights were specified and must be addressed in concert in order to provide education for all. The right of access to education-education must be available for, accessible to and inclusive of all children whether male or female gender. The right to quality education-education needs to be child-centred, relevant and embrace a broad curriculum, and be appropriately resourced and monitored. The right to respect within the learning environmenteducation must be provided in a way that is consistent with human rights, equal respect for culture, religion and language and free from all forms of violence.

UNESCO estimates that, an estimated $\$ 11$ billion per year is necessary to reach the 2015 EFA goals. ${ }^{51}$ The disparity between need and aid is apparent: aid sent to low-income countries to provide basic education in 2004 and 2005 was at an average of \$3.1 billion per year. The Fast Track Initiative (FTI) provides one of the most promising paths to universal primary education by 2015. Set up as a partnership between donors and developing countries and non-governmental organizations, the FTI endorses developing countries that put primary education at the forefront of their domestic efforts and develop sound national education plans. Nigeria is already maximizing these resources for the advancement of the younger generation.

The Convention on the Elimination of All Forms of Discrimination against Women (CEDAW), adopted in 1979 by the UN General Assembly and acceded to by 180 States, sets down rights for women including freedom from discrimination and equality under the law. CEDAW

\footnotetext{
${ }^{49}$ Female Education in Nigeria. Available at http://en.wikipedia.org/w/index.php?oldid613033161.

${ }^{50}$ UNICEF/UNESCO: A Human Rights-Based Approach to Education for All, (UNICEF, September 2007).

${ }^{51}$ Sub-Saharan Africa "Very Far" from Achieving EFA Goals, by UNESCO, THE GUARDIAN (Thursday, April 16, 2015).
} 
emphasises that, the rights and equality of woman is also the key to the survival and development of children and to building healthy families, communities and nations. Article 10 pinpoints nine changes that must be addressed in order to help Nigerian women and other women suffering from gender disparity. Firstly, there must be the same conditions for careers, vocational guidance, and for the achievement of diplomas in educational establishments of all categories in rural as well as in urban areas. This equality shall be ensured in pre-school, general, technical, professional and higher technical education, as well as in all types of vocational training.

Secondly, there must be access to the same curricula, the same examinations, teaching staff with qualifications of the same standard and school premises and equipment of the same quality. The third is the elimination of any stereotyped concept of the roles of men and women at all levels and in all forms of education. This is encouraged by coeducation and other types of education which will help to achieve this and, in particular, by the revision of textbooks and school programs and the adaptation of teaching methods. Fourthly, there must be the same opportunities to benefit from scholarships and other study grants. Similarly, and fifthly, there must be the same opportunities of access to programs of continuing education, including adult and functional literacy programs, particularly those aimed at reducing, at the earliest possible time, any gap in education existing between men and women. The sixth is the reduction of female student drop-out rates and the organization of programs for girls and women who have left school prematurely. The seventh concern listed is that, there must be same opportunities to participate actively in sports and physical education. Lastly, there must be access to specific educational information to help to ensure the health and well-being of families, including information and advice on family planning.

\section{CONCLUSION}

To empower women in Nigeria, enhanced educational opportunities are considered expedient. Consequently, the following suggestions have been indicated $^{52}$ as relevant in the process. First, that the primary instrument to achieve socio-economic empowerment i.e., education mainstreaming should be used in a more effective and practical way so as to make real progress towards the attainment of the MDGs "education for all” goal realizable. Furthermore, that the secondary instrument i.e., specific, targeted actions such as abolition of school fees, free school uniforms, free feeding etc.

\footnotetext{
${ }^{52}$ Female Education in Nigeria. Available at http://en.wikipedia.org/w/index.php?oldid=613033161.
} 
should be utilized as a complement of mainstreaming strategies. Moreover, that the imperialist male-gender privilege, biased traditional and religious myths impeding women's education should be de-emphasised in Nigerian society. Also, an empowering educational approach, incorporating women as invaluable partners for social development should be encouraged. Finally, that skills, capabilities and achievements should henceforth take preeminence over obnoxious gender stereotypes in classifying and rewarding people in Nigeria. These concerted efforts have the prospects of enhancing reproductive rights, women empowerment and national development. 